\title{
POCZYTALNOŚĆ I WINA PSYCHOPATY W ŚWIETLE EWOLUCYJNYCH KONCEPCJI GENEZY PSYCHOPATII
}

\section{WPROWADZENIE}

Problematyka odpowiedzialności karnej psychopatów oraz kwestia zabezpieczenia społeczeństwa przed jednostkami stwarzającymi zagrożenie z powodu zaburzeń osobowości sa aktualnie przedmiotem ważnej debaty społecznej i naukowej ${ }^{1}$, związanej z uchwaleniem kontrowersyjnej ustawy o postępowaniu wobec osób z zaburzeniami psychicznymi, stwarzających zagrożenie dla życia, zdrowia lub wolności seksualnej innych osób ${ }^{2}$. Niewątpliwie jest to istotny problem, gdyż psychopatia występuje w społeczeństwie równie często jak schizofrenia (1-2\% populacji) - w jednomilionowym mieście żyje około 10-20 tysięcy psychopatów. Przeciętnie $20 \%$ kobiet i mężczyzn przebywających w zakładach karnych to właśnie psychopaci. Ponadto sa oni sprawcami ponad 50\% najpoważniejszych przestępstw ${ }^{3}$. Duże znaczenie maja także statystyki mówiące o zachowaniu się psychopatów po odbyciu kary. Po opuszczeniu zakładu karnego wracają oni na ścieżkę „zbrodni” prawie dwukrotnie częściej niż inni przestępcy, a ponadtrzykrotnie częściej dopuszczają się w recydywie czynów zabronionych z użyciem przemocy ${ }^{4}$.

Kim jest psychopata? Termin psychopatia wywodzi się z dwóch greckich słów: psyche (czyli dusza) i pathos (czyli cierpienie). Historyczne znaczenie tego terminu oznacza więc bliżej niezidentyfikowaną chorobę duszy. W takich kategoriach ujmowano psychopatię w dawniejszych pracach poświęconych odpowiedzialności karnej, np. Juliusz Makarewicz w komentarzu do Kodeksu

\footnotetext{
${ }^{1}$ Chodzi m.in. o powszechnie znany przypadek Mariusza T. skazanego w czasach PRL na karę śmierci, która w okresie politycznej zmiany ustroju (w związku z wejściem w życie regulacji amnestyjnych) zamieniono na karę 25 lat pozbawienia wolności. Zob. ustawę z 7 grudnia $1989 \mathrm{r}$. o amnestii, Dz. U. 1989, Nr 64, poz. 390.

${ }^{2}$ Dz. U. 2014, poz. 24.

${ }^{3}$ Zob. R. D. Hare, Psychopaci sq wśród nas, Kraków 2008, s. 115; J. Sikora, Problem psychopatów w więzieniu, Warszawa 1958.

${ }^{4}$ Zob. S. D. Hart, P. R. Kropp, R. D. Hare, Performance of Male Psychopaths Following Conditional Release from Prison, „Journal of Consulting and Clinical Psychology” 56, 1988, nr 2; R. C. Serin, R. D. Peters, H. E. Barbaree, Predictors of Psychopathy and Release Outcome in a Criminal Population, „Psychological Assessment: A Journal of Consulting and Clinical Psychology" $2,1990, \mathrm{nr} 4$.
} 
karnego z 1932 r. wspominał o braku poczytalności sprawcy „z powodu anormalnego rozwoju życia duchowego"s. Do dzisiaj można jeszcze niekiedy natknąć się na takie rozumienie tego zjawiska ${ }^{6}$.

Zainteresowanie psychopatią siega XIX w. Philippe Pinel opisał psychopatię jako „szaleństwo bez delirium”: psychopata zachowuje się tak, jakby nie odczuwał żadnych wyrzutów sumienia, a wyrządzone przez niego zło różni się od złych czynów ludzi zdrowych ${ }^{7}$. „Zasługą” Pinela było wypuszczenie części psychopatów z więzień i traktowanie ich jak ludzi chorych, a nie do szpiku kości złych ${ }^{8}$. James Cowles Prichard postawił znak równości pomiędzy „,moralnym szaleństwem" a psychopatią. Psychopata cierpi na chorobę psychiczna, charakteryzująca się nieprawidłowymi procesami emocjonalnymi, skutkującymi nienormalnymi, niemoralnymi zachowaniami, przy jednoczesnym braku zakłóceń w zakresie intelektu oraz zdolności do logicznego myślenia. Psychopata nie jest nieracjonalny - wręcz przeciwnie, wykazuje dużą sprawność intelektualna, która nie powstrzymuje go jednak przed wyrządzaniem zła ${ }^{9}$. Kluczowym momentem w studiach nad zachowaniami psychopatycznymi była praca Herveya Cleckleya Mask of Sanity (1941). Cleckley scharakteryzował pewną część swoich pacjentów jako inteligentnych i elokwentnych rozmówców, posiadających niezwykły urok osobisty, zdolność do oczarowania swojego interlokutora, a jednocześnie skłonnych do popełniania czynów gwałtownych i brutalnych ${ }^{10}$. Choć praca Cleckleya nadała nowego impetu badaniom poświęconym psychopatii, to dopiero prace Roberta D. Hare'a pozwoliły na jej zrozumienie i opisanie w języku, w którym zwroty literackie ustapiły miejsca terminom medycznym i psychologicznym. W czasie, w którym Hare zają się tym problemem, psychopatia często mylona była z socjopatią i antysocjalnymi zaburzeniami osobowości ${ }^{11}$. Hare opracował tzw. skalę obserwacyjna skłonności psychopatycznych ${ }^{12}$. Psychopata posiada łatwość wysławiania się i urok osobisty, jest egocentrykiem mającym przesadne poczucie własnej wartości, nie odczuwa empatii, wstydu, żalu, nie poczuwa się do winy, nie miewa wyrzutów sumienia, wykazuje skłonność do manipulacji i oszustwa. Odchylenia społeczne charakteryzujące psychopatię to m.in.: impulsywność i brak poczucia odpowiedzialności ${ }^{13}$. Psychopaci lekceważą zobowiązania spo-

\footnotetext{
${ }^{5}$ J. Makarewicz, Kodeks karny z komentarzem, Lwów 1938, s. 91.

${ }^{6}$ Zob. R. D. Hare, op. cit., s. 38. Formuła „anormalnego rozwoju życia duchowego”, streszczajaca istotę zjawisk określanych później konsekwentnie mianem „psychopatii”, przewija się w literaturze karnistycznej po dziś dzień. Na potrzeby analizy karnistycznej psychopatia jest określana jako anomalia osobowości, zaburzenia w sferze rozwoju moralnego, uczuciowości wyższej, woli i w sferze popędów. Zob. M. Ciosek, Psychologia sqdowa i penitencjarna, Warszawa 2003, s. 203; A. Zoll, w: G. Bogdan et al., Kodeks karny. Część ogólna. Komentarz, t. 1: Komentarz do art. 1-116 k.k., red. A. Zoll, Warszawa 2007, s. 474.

${ }^{7}$ H. M. Cleckley, The Mask of Sanity, Augusta, Georgia 1982, s. 242.

${ }^{8}$ Ibidem, s. 443.

${ }^{9}$ Zob. J. Macpherson, Mental Affections: An Introduction to the Study of Insanity, Macmillan 1899, s. 300

${ }^{10}$ H. M. Cleckley, op. cit., s. 40 .

${ }^{11}$ R. D. Hare, op. cit., s. 40 i n.

${ }^{12}$ Ibidem, s. 51.

${ }^{13}$ Ibidem, s. 53.
} 
łeczne, o ile nie są one po ich myśli. W związku z brakiem możliwości odczuwania negatywnych emocji społecznych (wstydu, żalu, obrzydzenia) psychopaci są niewrażliwi na stosowane kary.

Badania dziewiętnasto- i dwudziestowiecznych psychologów zaowocowały lepszym zrozumieniem zjawiska psychopatii. W dalszym ciagu brakowało jednak dobrej odpowiedzi na pytanie o genezę psychopatii. Jeśli cechy psychopatyczne danej osoby nie ujawniły się po wypadku ${ }^{14}$, lecz ktoś po prostu urodził się psychopata, to należałoby się zastanowić, dlaczego dana osoba jest „z natury" psychopata? Odpowiedzi na to pytanie udzielają najnowsze koncepcje psychopatii, w szczególności jej ujęcie jako alternatywna strategia ewolucyjna. Skłaniają one do poszukiwania bardziej adekwatnych kategorii normatywnych dla tego rodzaju wypadków w sferze prawa karnego ${ }^{15}$. Przyjrzyjmy się im bliżej w niniejszych rozważaniach ${ }^{16}$.

\section{EWOLUCYJNA GENEZA PSYCHOPATII}

Jedna z najbardziej przekonujących i kompleksowych hipotez rozwiązujących zagadkę genezy psychopatii została zaproponowana na gruncie nauk ewolucyjnych. Teoria ewolucji Karola Darwina (kojarzona najczęściej z naukami ewolucyjnymi) to dzisiaj jedynie wierzchołek góry lodowej zwanej ewolucjonizmem ${ }^{17}$. W perspektywie nauk ewolucyjnych psychopatii nie sposób ujmować ani w kategoriach choroby psychicznej, ani jako zła wcielonego. Psychopatia może być natomiast uznana za stabilną strategię ewolucyjna, która jest alternatywą dla strategii przyjmowanej przez zdecydowaną większość społeczeństwa (czyli dla moralności) ${ }^{18}$. Psychopaci w sposób konsekwentny wcielają w życie swoją strategię przetrwania, opartą na oszustwie, kłamstwie, manipulacji, a także wykorzystywaniu dobrej wiary innych osób. W świetle ewolucjonizmu, psychopaci czynia to w celu osiagnięcia ewolucyjnego sukcesu: pozyskania jak największej ilości zasobów i przekazania swoich genów. Ewolucjoniści pytaja, skąd wzięła się skłonność ludzi do zachowań „dobrych”, zastanawiają się także nad pochodzeniem „zła”. Przed omówieniem ewolucyjnych uwarunkowań psychopatii jako zjawiska niepożądanego społecznie należy zwrócić uwagę na ewolucyjne wyjaśnienia moralności.

${ }^{14}$ Zob. J. Parker, Phineas Gage: The Man with a Hole in His Head, Educators Publishing Service 2008.

${ }^{15}$ Zagadnieniem „adekwatności prawnokarnych instytucji mogących mieć obecnie zastosowanie wobec naruszających normy prawa karnego psychopatów" zajmowała się także A. Michalska-Warias, Prawnokarne znaczenie psychopatii, „Palestra” 2009, nr 9-10, s. 56 i n.

${ }^{16}$ Słowa podziękowania kierujemy do Agnieszki Barczak-Oplustil, Szymona Tarapty i Dominika Zająca z Uniwersytetu Jagiellońskiego, których cenne uwagi ułatwiły przygotowanie artykułu.

${ }_{17}$ Zob. więcej: W. Z. Załuski, Ewolucyjna filozofia prawa, Warszawa 2009, s. 38.

${ }_{18}$ Wartość ewolucyjnego wyjaśniania psychopatii podnoszą badania empiryczne, przeprowadzane z użyciem metod pozwalających na obrazowanie mózgu (tzw. imaging studies). Między innymi udało się dzięki nim postawić hipotezę, że zachowania antyspołeczne, w tym psychopatyczne, maja podstawy neuronalne. 
Na pytanie o korzenie naszych zachowań moralnych udzielano różnych odpowiedzi ${ }^{19}$. Najbardziej wiarygodnego ewolucyjnego wyjaśnienia zachowań moralnych dostarcza teoria, zgodnie z która moralność rozumiana jest jako rozwinięcie instynktów społecznych (VMOSI - view of morality as an outgrowth of the social instincts) ${ }^{20}$. Nasze zachowania oraz przekonania o tym, co dobre, a co złe, maja ewolucyjny rodowód. Moralność nie jest jedynie naszym wyborem, lecz strategia przetrwania. Wyewoluowaliśmy w „zwierzęta” moralne, ponieważ życie w grupach wymagało wypracowania mechanizmów współpracy i koegzystencji. W związku z tym pewne zaczątki moralności można zaobserwować u innych ssaków naczelnych, choć ich protomoralność różni się od ludzkiej moralności stopniem skomplikowania. Teoria ta zakłada monizm natury i kultury: nasze uposażenie biologiczne (historia ewolucyjna) ma wpływ na naszą kulturę. Ludzie sa moralni, ponieważ z punktu widzenia ewolucji moralność jest strategią opłacalna, pozwalająca na przetrwanie i odniesienie sukcesu reprodukcyjnego. Życie w małych grupach opartych na współpracy w celu zbierania pożywienia, przemieszczania się, obrony przed drapieżnikami, ochrony potomstwa czy poszukiwania schronienia - czyli grupach, których głównym celem było przetrwanie i rozwój - wymagało określenia norm postępowania wiążących członków grupy. Wraz z rozwojem coraz bardziej skomplikowanych społeczeństw zestaw reguł powiększał się i utrwalał. Oczywiście niektóre jednostki postanawiały wyłamać się z tego porządku i zamiast współdziałać, wykorzystywały wspólny wysiłek reszty grupy. Doprowadziło to do ewolucyjnego „wyścigu zbrojeń”. Członkowie grup poszukiwali nowych sposobów wykrywania i skutecznego karania jednostek wykorzystujacych grupę do własnych celów. Z kolei jednostki te poszukiwały najskuteczniejszych strategii oszustwa w celu zwiększenia szansy na przechytrzenie grupy.

Zaleta teorii VMOSI jest fakt, że znajduje ona potwierdzenie w wynikach badan przeprowadzanych w innych dyscyplinach naukowych, takich jak neuroscience czy prymatologia. Neuronaukowcy rozpoczęli proces identyfikowania części mózgu odpowiedzialnych za myślenie moralne ${ }^{21}$. Z kolei prymatolodzy skoncentrowali się na identyfikacji zachowań moralnych wśród ssaków naczelnych $^{22}$. Bez wątpienia koncepcja moralności jako rozwinięcia instynktów

${ }^{19}$ Należy wymienić tutaj tzw. venner theory, która nie znalazła jednak potwierdzenia w danych empirycznych (zob. F. de Waal, Primates and Philosophers: How Morality Evolved: How Morality Evolved, Princeton University Press, Princeton 2009, s. 6-21) oraz teorię moralności jako preadaptacji, która z kolei posiada mocno spekulatywny charakter (zob. F. J. Ayala, What the Biological Sciences Can and Cannot Contribute to Ethics?, w: F. J. Ayala, R. Arp, Contemporary Debates in Philosophy of Biology, John Wiley \& Sons 2009, s. 316-324).

${ }^{20}$ Zob. F. de Waal, op. cit., passim.

${ }^{21}$ Zob. M. S. Gazzaniga, The Ethical Brain: The Science of Our Moral Dilemmas, New York 2006; Zob. W. Sinnott-Armstrong, Moral Psychology: The Neuroscience of Morality: Emotion, Brain Disorders, and Development, MIT Press, Cambridge 2008; L. Tancredi, Hardwired Behavior: What Neuroscience Reveals about Morality, Cambridge University Press, Cambridge 2005; J. Verplaetse, Localizing the Moral Sense: Neuroscience and the Search for the Cerebral Seat of Morality, 1800-1930, Springer 2009; J. Verplaetse, J. D. Schrijver, S. Vanneste, The Moral Brain: Essays on the Evolutionary and Neuroscientific Aspects of Morality, Springer 2009.

${ }^{22}$ M. Midgley, The Ethical Primate: Humans, Freedom and Morality, Routledge 2002; F. de Waal, op. cit.; idem, The Bonobo and the Atheist: In Search of Humanism among the Primates, W. W. Norton 2013. 
społecznych jest dzisiaj najpoważniejszym kandydatem branym pod uwagę przy wyjaśnianiu genezy moralności. Ewolucyjne wyjaśnienie zachowań moralnych i treści reguł moralnych sprawiło, że zainteresowano się również pochodzeniem postawy niemoralnej. Okazuje się, że zachowania niemoralne (których klasycznym źródłem może być psychopatia) oraz podzielana przez większą część ludzi moralność to dwie strony tej samej, ewolucyjnej monety.

Rezultatem badań nad wyjaśnieniem genezy psychopatii jest hipoteza głosząca, że psychopatami są osoby wykorzystujące „oszustwo” jako ewolucyjną strategię przetrwania, która jest strategią alternatywna dla moralności. Urok osobisty, przesadne poczucie własnej wartości, brak empatii, niezdolność do odczuwania wstydu, brak wyrzutów sumienia, skłonność do manipulacji i oszustwa - wszystkie te cechy, pod pewnymi warunkami i w odpowiednich okolicznościach, moga spełniać najważniejsze ewolucyjne cele: pozyskanie zasobów potrzebnych do przetrwania i zapewnienie sukcesu reprodukcyjnego. Ta ciekawa hipoteza badawcza stała się przedmiotem studiów w szeregu dyscyplinach naukowych, jak choćby w ewolucjonizmie, genetyce behawioralnej, neurobiologii, neuronauce poznawczej czy w ewolucyjnej teorii gier. Uznanie psychopatii za alternatywną strategię ewolucyjną oznacza, że psychopatia jest złożonym systemem cech poznawczych, emocjonalnych, behawioralnych, który ma biologiczne podstawy, przejawiające się w specyficznej budowie i funkcjonowaniu mózgu ${ }^{23}$.

Oszukiwanie nie miałoby sensu, gdyby nie przynosiło korzyści, pozwalając zarazem uniknąć kary. Henry Harpending i Jay Sobus wykorzystali teorie gier w celu sprawdzenia, czy strategia przetrwania oparta na oszustwie może zapewnić sukces reprodukcyjny. Wyniki okazały się zaskakujące. Oszustwo może być efektywną strategia postępowania w przypadku małej liczby oszustów, którzy nie mają większych trudności ukrycia się, np. w coraz bardziej zatomizowanych społeczeństwach o dużym stopniu anonimowości z możliwościa swobodnego przemieszczania się. Na pierwszy rzut oka mogłoby się wydawać, że współczesne społeczeństwa - zanurzone w systemach prawnych i wyposażone w organy ścigania - powinny sobie poradzić z konsekwentnymi oszustami, jednakże proste eksperymenty matematyczne pokazuja, że w świecie pełnym osób chętnie ze sobą współpracujących strategia oszusta może przynieść dobre efekty ${ }^{24}$.

Tajemnicę psychopatii i zachowań antyspołecznych odsłoniły badania nad mózgiem. Badania te polegaja przede wszystkim na obrazowaniu mózgu, czyli obserwacji jego funkcjonowania podczas wykonywania zleconych zadań. Badania takie przeprowadzane są mi.in. za pomoca funkcjonalnego rezonansu magnetycznego (fMRI). Badania z użyciem fMRI pozwalają określić, które części mózgu są zaangażowane - i z jaką intensywnością - w wykonanie zle-

${ }^{23}$ A. L. Glenn, A. Raine, The Immoral Brain, w: J. Verplaetse, J. D. Schrijver, S. Vanneste, op. cit., s. 52-74.

${ }^{24}$ H. C. Harpending, J. Sobus, Sociopathy as an Adaptation, „Ethology and Sociobiology” 8, 1987, nr 1, s. 63-72. 
conego zadania oraz czy mózg badanej osoby działa w sposób prawidłowy ${ }^{25}$. Wiele o funkcjonowaniu ośrodkowego układu nerwowego powiedziały nam także studia nad osobami, które w wyniku wypadku doznały mechanicznych uszkodzeń mózgu. Różnorodne urazy pacjentów wpływały na ich zachowania się, co pozwalało określić, które partie mózgu odpowiadają za określone zachowania $^{26}$. Studia nad neurobiologicznymi podstawami zachowań antyspołecznych i psychopatii pozwoliły sformułować dużą liczbę hipotez wskazujących na związek pomiędzy nieprawidłowościami w budowie lub funkcjonowaniu mózgu a cechami behawioralnymi psychopaty.

Poszukiwanie biologicznych podstaw psychopatii to trudne zadanie, ponieważ cech charakteryzujących psychopatię jest co najmniej kilkanaście ${ }^{27}$. Naukowcom udało się jednak wyróżnić dwie części mózgu kluczowe dla psychopatii: amygdale i korę okołooczodołową $(\mathrm{OFC})^{28}$. Amygdala jest częścia mózgu odpowiedzialną m.in. za procesy emocjonalne. Innymi słowy, jakość naszego życia emocjonalnego zależy od prawidłowego funkcjonowania amygdali. Badania wykazały, że amygdala ma zmniejszoną objętość w przypadku osób dopuszczających się agresywnych zachowań ${ }^{29}$, jak również wykazuje zmniejszoną aktywność w przypadku klasycznych psychopatów ${ }^{30}$. Jeśli chodzi o OFC, to powiązano zmniejszenie objętości materii szarej w korze oczodołowej ze skłonnością do zachowań antyspołecznych ${ }^{31}$. Udało się ustalić, że te dwie części mózgu są odpowiedzialne za rozwój psychopatii, jednak ich uszkodzenia nie prowadziły do pojawienia się wszystkich klasycznych cech psychopatii. Odchylenia od normy zaobserwowano również w innych rejonach mózgu. $\mathrm{Na}$ przykład zmniejszenie objętości materii szarej w obszarze przedczołowym jest typowe dla ludzi wykazujących zachowania psychopatyczne i antyspołeczne ${ }^{32}$.

${ }^{25}$ Zob. N. K. Logothetis, The Neural Basis of the Blood-Oxygen-Level-Dependent Functional Magnetic Resonance Imaging Signal, „Philosophical Transactions of the Royal Society of London. Series B: Biological Sciences” 357, 2002, nr 1424, s. 1003-1037.

${ }^{26}$ Zob. J. Grafman et al., Frontal Lobe Injuries, Violence, and Aggression: A Report of the Vietnam Head Injury Study, „Neurology” 46, 1996, nr 5, s. 1231-1238; R. W. Heinrichs, Frontal Cerebral Lesions and Violent Incidents in Chronic Neuropsychiatrie Patients, „Biological Psychiatry" 25, 1989, nr 2, s. 174-178; M. Macmillan, An Odd Kind of Fame: Stories of Phineas Gage, MIT Press, Cambridge 2002.

${ }^{27}$ R. D. Hare, S. D. Hart, T. J. Harpur, Psychopathy and the DSM-IV Criteria for Antisocial Personality Disorder, ,Journal of Abnormal Psychology” 100, 1991, nr 3, s. 391-398.

${ }^{28}$ R. J. R. Blair, Applying a Cognitive Neuroscience Perspective to the Disorder of Psychopathy, „Development and Psychopathology” 17, 2005, nr 3, s. 865-891.

${ }^{29}$ R. A. Richell et al., Trust and Distrust: The Perception of Trustworthiness of Faces in Psychopathic and Non-Psychopathic Offenders, „Personality and Individual Differences” 38, 2005, nr 8, s. 1375-1384.

${ }^{30}$ K. A. Kiehl et al., Limbic Abnormalities in Affective Processing by Criminal Psychopaths as Revealed by Functional Magnetic Resonance Imaging, „Biological Psychiatry” 50, 2001, nr 9, s. 677-684.

${ }^{31}$ M. P. Laakso et al., Prefrontal Volumes in Habitually Violent Subjects with Antisocial Personality Disorder and Type 2 Alcoholism, „Psychiatry Research” 114, 2002, nr 2, s. 98-102.

${ }^{32}$ A. Raine et al., Reduced Prefrontal Gray Matter Volume and Reduced Autonomic Activity in Antisocial Personality Disorder, „Archives of General Psychiatry” 57, 2000, nr 2, s. 199-127; Y. Yang et al., Volume Reduction in Prefrontal Gray Matter in Unsuccessful Criminal Psychopaths, „Biological Psychiatry” 57, 2005, nr 10, s. 1103-1108. 
W rozwoju psychopatii ważną rolę pełni zmniejszona aktywność tych części mózgu, które odpowiadają za kontrolę zachowania i odczuwanie strachu ${ }^{33}$. Innym regionem mózgu odpowiedzialnym za powstanie i rozwój psychopatii jest zakręt kątowy (angular gyrus), który ma wpływ na odczuwanie złożonych emocji społecznych i łączy doświadczenia o dużym ładunku emocjonalnym z ocenami moralnymi (np. ukradłem coś i miałem z tego powodu wyrzuty sumienia, dlatego uważam kradzież za zło i nigdy więcej tego nie zrobię). U psychopatów działanie zakrętu kątowego jest zaburzone ${ }^{34}$. Podobnie jest w przypadku środkowo/brzusznej kory przedczołowej (medial/ventral prefrontal cortex), zawiadującej przetwarzaniem społecznych i emocjonalnych bodźców ${ }^{35}$. Mózg psychopaty różni się od mózgu osoby „moralnej” w jeszcze inny sposób. Psychopaci wykazują mianowicie daleko idąca specjalizację w zakresie oszustwa, a jest to złożona czynność poznawcza, na którą składają się umiejętność ukrywania prawdy, doskonała pamięć wszystkich szczegółów kłamstwa (trudniej jest kłamać niż mówić prawdę!), ocena stopnia wiarygodności oszukańczych treści czy umiejętność modyfikowania strategii oszustwa w czasie rzeczywistym. Ewolucja wyposażyła psychopatów w mózgi, których obszary łączone z oszustwem i kłamstwem sa zwykle powiększone o $22-26 \%$ w stosunku do grup kontrolnych ${ }^{36}$.

Hipoteza, zgodnie z która psychopatia może być alternatywna strategia ewolucyjną w stosunku do moralności, znalazła potwierdzenie w badaniach neurobiologicznych, ekonomicznych i genetycznych. Obecnie stanowi jedno z najbardziej wiarygodnych wyjaśnień genezy zachowań psychopatycznych.

\section{PSYCHOPATIA A NIEPOCZYTALNOŚĆ}

Koncepcja psychopatii jako alternatywnej strategii ewolucyjnej stawia przed naukami prawnymi szereg interesujacych wyzwań. Dotyczy to w szczególności prawa karnego, które opiera się na ustaleniu indywidualnej winy za popełnienie czynu zabronionego. Pierwszy aspekt prawnokarnej ewaluacji zachowań psychopatycznych można przedstawić zwięźle w następujący sposób: jeśli moralność (bycie jednostką moralna) jest strategia adaptacyjna, która umożliwia nam przetrwanie, to uznanie psychopatii za alternatywną strategię ewolucyjna po prostu nie pozwala na określenie psychopatów mianem ludzi chorych. Z ewolucyjnego punktu widzenia psychopatia jest jedynie kolejna, skuteczną strategia, zapewniająca przetrwanie i sukces reprodukcyjny danej jednostki. Nie ma więc nic wspólnego z patologią czynności psychicznych.

${ }^{33}$ N. Birbaumer et al., Deficient Fear Conditioning in Psychopathy: A Functional Magnetic Resonance Imaging Study, „Archives of General Psychiatry” 62, 2005, nr 7, s. 799-508.

${ }_{34}$ A. L. Glenn, A. Raine, R. A. Schug, The Neural Correlates of Moral Decision-Making in Psychopathy, „Molecular Psychiatry” 14, 2009, nr 1, s. 5-6.

${ }_{35}$ D. Lapierre, C. M. J. Braun, S. Hodgins, Ventral Frontal Deficits in Psychopathy: Neuropsychological Test Findings, „Neuropsychologia” 33, 1995, nr 2, s. 139-151.

${ }^{36}$ Y. Yang et al., Prefrontal white Matter in Pathological Liars, „The British Journal of Psychiatry" 187, 2005, nr 4, s. 320-325. 
Zaliczenie psychopatów do grona osób niepoczytalnych sprawiało osobliwe trudności, opisywane na kartach przedwojennej encyklopedii prawa karnego przez Witolda Łuniewskiego:

Typ patologiczny, znany pod nazwą „psychopatów amoralnych” „moral insanity” i w. innemi nazwami jest od urodzenia pozbawiony zdolności kierowania się w swem postępowaniu takiemi motywami normalnego życia uczuciowego, jak współczucie, litość, uczucia etyczne. Jeżeli brakowi uczuć etycznych nie towarzyszą inne przejawy patologiczne psychiki, może powstać wątpliwość, czy taki patologiczny brak sam przez się odpowiada warunkom niepoczytalności ze względu na to, że brak uczuć moralnych u człowieka normalnego bywa zarówno w życiu jak i prawie karnem oceniany jako moment raczej obciążający, niż łagodzący ${ }^{37}$.

We współczesnej literaturze karnistycznej ${ }^{38}$ wspomina się o psychopatii przy okazji omawiania przepisu wyłaczającego odpowiedzialność karna sprawcy niepoczytalnego (art. $25 \S 1$ d.k.k. z 1969 r. i art. $31 \S 1$ k.k.). Zaznaczyć przy tym należy, że niepoczytalność, o której mowa w art. $31 \S 1$ k.k., jest pojęciem języka prawnego ${ }^{39}$ i musi być w związku z tym kojarzona z choroba psychiczna, upośledzeniem umysłowym czy innym zakłóceniem czynności psychicznych, prowadzącymi do niemożliwości rozpoznania znaczenia czynu lub pokierowania przez człowieka jego postępowaniem (mieszana metoda określania niepoczytalności). Umiejscowienie prawnokarnej ewaluacji psychopatii w obszarze art. $31 \S 1$ k.k. musi prowadzić do wniosku, że psychopata nie jest osobą niepoczytalna, gdyż psychopatię trudno uznać za któreś ze źródeł (przyczyn) niepoczytalności wskazanych w art. 31 § 1 k.k.

Psychopatia przede wszystkim nie jest chorobą psychiczna ${ }^{40}$, nie jest również z pewnością upośledzeniem umysłowym ${ }^{41}$. Bywa ona jednakże zaliczana do trzeciego rodzaju źródeł wyłączających poczytalność, a mianowicie do „innego zakłócenia czynności psychicznych”42. Rzuca się jednak w oczy duża ostrożność niektórych autorów w zaliczeniu psychopatii do tej kategorii nor-

${ }^{37}$ W. Łuniewski, Niepoczytalność, w: Encyklopedja podręczna prawa karnego, t. 3, red. W. Makowski, Warszawa 1937, s. 1087.

${ }^{38}$ M. Budyn-Kulik, w: M. Budyn-Kulik et al., Prawo karne materialne. Czesść ogólna, Warszawa 2009, s. 275; K. Buchała, w: K. Buchała et al., Komentarz do kodeksu karnego. Część ogólna, red. K. Buchała, Warszawa 1994, s. 203; J. K. Gierowski, L. K. Paprzycki, Niepoczytalność i poczytalność ograniczona, w: System prawa karnego, t. 4, red. L. K. Paprzycki, Warszawa 2013, s. 528 i n.; J. Giezek, w: M. Bojarski, J. Giezek, Z. Sienkiewicz, Prawo karne materialne. Część ogólna i szczególna, red. M. Bojarski, Warszawa 2007, s. 192; A. Marek, Prawo karne, Warszawa 2009, s. 157-158; Ł. Pohl, Prawo karne. Wyktad części ogólnej, Warszawa 2012, s. 310-311; J. Warylewski, Prawo karne. Część ogólna, Warszawa 2009, s. 334; W. Wróbel, A. Zoll, Polskie prawo karne. Część ogólna, Kraków 2012, s. 396.

${ }^{39}$ Zob. art. 31 § 3, art. 94 § 1 i art. $95 \S 1$ k.k., a także: Nowe kodeksy karne $z 1997$ r. z uzasadnieniami, red. I. Friedrich-Michalska, B. Stachurska-Marcińczak, Warszawa 1997, s. 135.

${ }^{40}$ Zob. A. Zoll, w: Kodeks..., s. 474; W. Łuniewski, Zarys psychiatrii sqdowej. Część ogólna, Warszawa 1950, s. 20.

${ }^{41} \mathrm{Na}$ temat upośledzenia umysłowego w rozumieniu art. $31 \S 1$ k.k. zob.: J. K. Gierowski, L. K. Paprzycki, op. cit., s. 525-527.

${ }^{42}$ K. Buchała, op. cit., s. 203; J. Leszczyński, Z problematyki karania psychopatów (głos $w$ dyskusji), „Palestra” 1975, nr 11, s. 27; A. Michalska-Warias, op. cit., s. 62; Ł. Pohl, op. cit., s. $310-311$. 
matywnej ${ }^{43}$. W istocie rzeczy na gruncie założeń alternatywnej strategii ewolucyjnej traktowanie psychopatii jako zakłócenia czynności psychicznych nie jest uzasadnione co najmniej z kilku powodów.

Psychopatia towarzyszy sprawcy „od zawsze” jako jego trwałe usposobienie, niezakłócone przez procesy socjalizacji, co nie pozwala uznać jej za „zakłócenie" funkcjonowania czynności psychicznych. Psychopatia nie dezorganizuje życia człowieka, lecz swoimi metodami skutecznie je organizuje w celu zapewnienia mu ewolucyjnego sukcesu. Termin „zakłócenie” sugeruje zmianę prawidłowego, niezakłóconego funkcjonowania psychiki człowieka w stan z jakichś powodów zakłócony, który może polegać np. na upojeniu alkoholowym, silnym afekcie, huśtawce nastrojów w okresach biologicznych przełomów itp. „Zakłócenia” mają to do siebie, że wywodzą się z jakiegoś źródła (odpowiednio: ze spożycia dużej ilości alkoholu; szczególnych okoliczności, w jakich znajduje się sprawca; zmian hormonalnych związanych z osiagnięciem określonego wieku). Ani wskazana periodyczność zakłóceń stanu psychicznego, ani żadne dodatkowe czynniki wpływające na pracę mózgu nie występują w wypadku psychopatii ujmowanej jako alternatywna strategia ewolucyjna ${ }^{44}$. Zakłócenia czynności psychicznych - jako jednego ze źródeł niepoczytalności - nie należy mylić z anomaliami w zakresie „zmysłu” moralnego, te ostatnie sa bowiem oceną określonego postępowania człowieka ze względu na przyjęty system aksjologiczny, a nie jego cecha. Uznanie psychopatii za „inne” zakłócenie czynności psychicznych oznaczałoby ponadto, że psychopata dopuszczający się czynu zabronionego zostałby w świetle prawa karnego zrównany z osobami chorymi psychicznie, np. cierpiącymi na schizofrenię czy paranoję, bądź z jednostkami upośledzonymi (debilitas mentalis, imbecillitas, idiota). Sytuacje te nie wydają się porównywalne w kontekście stwierdzenia bądź wykluczenia zdolności do poczytania konkretnej osobie odpowiedzialności za czyn zabroniony ${ }^{45}$.

Skoro psychopatia nie jest żadną z przyczyn niepoczytalności wskazanych $\mathrm{w}$ art. $31 \S 1 \mathrm{k} . \mathrm{k}$., to nie ma już dla wykluczenia stosowania tego przepisu znaczenia, czy psychopata mógł rozpoznać znaczenie czynu lub pokierować swoim postępowaniem. Wynika z tego, że w świetle art. $31 \mathrm{k} . \mathrm{k}$. psychopata jest osobą poczytalna. Z dotychczasowych ustaleń płynie jeszcze bardziej radykalny wniosek, że mianowicie psychopata nie tylko nie jest niepoczytalny, lecz w ogóle nie może być niepoczytalny w rozumieniu tego przepisu ${ }^{46}$. Powody, dla których psychopatia nie może być źródłem niepoczytalności w rozumieniu art. $31 \S 1$ k.k., sprawiaja, że stopień jego winy nie może zostać również

${ }^{43}$ Zob. A. Zoll, w: Kodeks..., s. 474; J. K. Gierowski, L. K. Paprzycki, op. cit., s. 528.

${ }^{44}$ J. K. Gierowski, L. K. Paprzycki, op. cit., s. 510, wskazując na istotę niepoczytalności z perspektywy psychiatryczno-psychologicznej, podkreślaja, że „mamy tu do czynienia ze specyficznym, ograniczonym w czasie, stanem psychicznym człowieka [...]”- M.M., R.Z.

${ }^{45} \mathrm{Na}$ temat problemów klasyfikacji zaburzeń psychicznych na gruncie psychologii zob. szerzej: S. Ładoś, Pozycja prawna oskarżonego z zaburzeniami psychicznymi, Warszawa 2013, s. $40-50$.

${ }^{46}$ Poza zakresem zaprezentowanego wniosku pozostaja oczywiście sytuacje, w których czynności psychiczne psychopaty zostaną zakłócone przez inne, dodatkowe czynniki, prowadzące do eskalacji gniewu, agresji czy wzburzenia tej osoby. 
umniejszony na zasadzie art. $31 \S 2$ k.k., regulującego konsekwencje prawne tzw. poczytalności ograniczonej ${ }^{47}$.

Konsekwencją takiego postawienia sprawy jest konieczność zrewidowania kategorii normatywnych, w ramach których powinny być oceniane czyny popełnione przez psychopatę, gdyż - powtórzmy - kodeksowa kategoria niepoczytalności (art. 31 k.k.) nie jest adekwatnym wzorcem wartościowania tego złożonego zjawiska. Całkowita rezygnacja z uwzględnienia „choroby duszy” sprawcy na etapie wartościowania jego czynu nie wydaje się konsekwencja zadowalająca. Mimo że psychopaci są z reguły osobami rozpoznajacymi faktyczne i prawne znaczenie swojego czynu oraz często bardzo racjonalnie dobierającymi środki prowadzące do osiagnięcia zamierzonych rezultatów, nie da się jednak in abstracto wykluczyć wpływu psychopatycznej osobowości na stopień rozeznania się sprawcy w moralnym znaczeniu czynu bądź na możliwości świadomego i wolnego kierowania swym postępowaniem. Te zaś okoliczności w każdym wypadku moga przemawiać za - choćby połowicznym - usprawiedliwieniem wyrządzonego przez człowieka zła.

\section{PSYCHOPATIA A PRZYPISANIE WINY}

Na gruncie koncepcji ujmującej psychopatię jako alternatywną strategię ewolucyjna psychopaci nie mają nic wspólnego z powszechnie pojmowana moralnością. Miliony lat ewolucji sprawiły, że są oni jednostkami, dla których takie pojęcia, jak odpowiedzialność, moralność czy poczucie sprawiedliwości, to jedynie puste, do niczego niezobowiązujące hasła. Można zaryzykować stwierdzenie, że psychopaci są niemoralni wyłącznie z perspektywy osób tradycyjnie „moralnych”; obiektywnie rzecz biorac, kierują się bowiem ewolucyjnie uwarunkowana, własną moralnościa. Czy biologiczne procesy ewolucyjne sa usprawiedliwieniem bezprawnych działań psychopatów?

Prawnokarne poczytanie danej osobie czynu zabronionego nie sprowadza się jedynie do stwierdzenia braku niepoczytalności sprawcy $\mathrm{w}$ rozumieniu art. $31 \S 1$ k.k. ${ }^{48}$, lecz jest kategoria o wiele bardziej pojemną ${ }^{49}$, obejmujacca wszystkie przesłanki postawienia sprawcy czynu zabronionego zarzutu winy, opartego na wyważeniu okoliczności, w których - według ocen społecznych - dana osoba powinna wziać na siebie odpowiedzialność za swój czyn i taką odpowiedzialnością zostać obarczona. Wina to odrębny aspekt struktury przestępstwa, aktualizujący konieczność uwzględnienia rozmaitych okoliczności,

${ }^{47}$ Odnośnie do mieszanej metody określenia ograniczonej poczytalności zob. A. Zoll, w: Kodeks..., s. 477; G. Rejman, Zasady odpowiedzialności karnej. Art. 8-21 KK. Komentarz, Warszawa 2009, s. 701. Odmiennie A. Wąsek, op. cit., s. 390, który uważa, że określenie stanu ograniczonej poczytalności nastapiło za pomocą metody psychologicznej.

${ }^{48}$ Na skłonność do zawężania kategorii poczytalności sugestywnie zwracał uwagę W. Łuniewski, Niepoczytalność..., s. 1084.

${ }^{49}$ Zob. interesujace uwagi terminologiczne: J. K. Gierowski, L. K. Paprzycki, op. cit., s. 502-506 . 
które winę mogą wyłączać bądź ograniczać. Ustawodawca wyróżnia kilka takich sytuacji, bacząc na ich ontologiczne, a w ślad za tym - prawne, właściwości. Inną sytuacją wyłączająca winę jest błąd co do kontratypu (art. 29 k.k.), inna - błąd co do prawa (art. 30 k.k.), inną wreszcie - stan wyższej konieczności (art. $26 \S 2$ k.k.) czy tzw. kolizja obowiązków (art. $26 \S 5$ k.k.) ${ }^{50}$. W doktrynie prawa karnego uznaje się ponadto, że np. błąd co do okoliczności stanowiącej znamię czynu zabronionego, jeśli jest usprawiedliwiony, wyłącza możliwość postawienia sprawcy zarzutu winy, mimo że okoliczność ta nie jest wyraźnie wskazana w żadnym przepisie k.k. (w szczególności w rozdziale określającym prawnokarne konsekwencje błędów, tj. w art. 28-30 k.k. $)^{51}$. W opisanym wypadku uzasadnieniem wyłączenia winy jest art. $1 \S 3$ k.k., wyrażający wprost starorzymską zasadę nullum crimen sine culpa.

Należy uznać, że również w wypadku czynów zabronionych popełnionych przez psychopatów ewentualna podstawą badania możliwości przypisania im winy za popełniony czyn lub uwolnienia ich od zarzutu popełnienia przestępstwa powinien być art. $1 \S 3 \mathrm{k} . \mathrm{k}$. Nie chodzi przy tym o wskazanie regulacji „automatycznie” usprawiedliwiającej każdego psychopatę, lecz o prawidłowe zidentyfikowanie podstawy normatywnej, w ramach której należy rozpatrywać tego rodzaju przypadki. Powtórzmy, jest nią naszym zdaniem klauzula winy z art. $1 \S 3$ k.k., nie zaś instytucja niepoczytalności z art. $31 \S 1$ k.k. Zmiana wzorca oceny na art. $1 \S 3$ k.k. jest uzasadniona $\mathrm{z}$ kilku powodów. Po pierwsze, są nim omówione wcześniej trudności w zaliczeniu psychopatów do osób z zakłóceniami czynności psychicznych. Po drugie, psychopata jest osoba, która posiada trwałe, ewolucyjne predyspozycje do funkcjonowania według alternatywnej moralności, co na stałe wyłącza go ze społeczności ludzi „moralnych". Jest to inna kategoria sytuacji niż zakłócenie czynności psychicznych, ujmowane w kategoriach patologicznej bądź niepatologicznej dysfunkcji mózgu. Po trzecie, art. $1 \S 3$ k.k. oferuje bardziej adekwatne niż art. $31 \S 1$ k.k. wzorce oceny.

Zajmijmy się przez moment tym ostatnim argumentem. Wyłączenie winy domaga się w każdym wypadku wskazania podstawy usprawiedliwienia czynu zabronionego popełnionego przez konkretną osobę. Usprawiedliwienie bada się według kryteriów obiektywno-subiektywnych, tzn. biorąc pod uwagę cechy zdarzenia, w jakich został postawiony sprawca czynu zabronionego, oraz okoliczności osobisto-indywidualne dotyczące sprawcy ${ }^{52}$. W wypadku czynów zabronionych popełnionych przez psychopatów taka wyważona, zindywidualizowana ocena, oparta na przesłankach obiektywno-subiektywnych, zmierzająca do rozważenia możliwości moralnego usprawiedliwienia czynu (legitymizująca funkcja winy z art. $1 \S 3$ k.k.), wydaje się szczególnie potrzebna, ponieważ pozwala uwzględniać stopień zinternalizowania przez daną oso-

\footnotetext{
${ }^{50} \mathrm{Na}$ temat istoty wszystkich okoliczności wyłączających winę zob. więcej: A. Barczak-Oplustil, Sporne zagadnienia istoty winy w prawie karnym. Zarys problemu, „Czasopismo Prawa Karnego i Nauk Penalnych" 2005, nr 2, s. 79 i n.

${ }^{51}$ Zob. W. Wróbel, A. Zoll, Polskie prawo karne. Część ogólna, Kraków 2012, s. 387, którzy zaznaczaja, że w opisanej sytuacji podstawy do wyłączenia winy można się dopatrzyć w treści art. $9 \S 2$ in fine k.k.

${ }^{52}$ Zob. W. Wróbel, A. Zoll, Polskie..., s. 394; A. Barczak-Oplustil, Sporne zagadnienia..., s. 86.
} 
bę norm społecznych, wiążący się z tym rozwój jej osobowości, przebieg życia wewnętrznego, stosunek do popełnionego czynu oraz indywidualne możliwości rozpoznania jego naganności. Nie są to pozbawione treści frazesy i w wypadku psychopatii organ prowadzący postępowanie karne nie może przejść nad nimi do porządku. Społeczna potrzeba karania nie usprawiedliwia instrumentalnego wykorzystywania przesłanki „winy w czasie czynu” jako zasłony dymnej dla eliminowania ze społeczeństwa niebezpiecznych sprawców. Sąd powinien zatem odnieść się do wskazanych okoliczności oraz uzasadnić, bacząc na art. 1 $\S 3$ k.k., że oskarżony ponosi winę za zarzucony mu czyn.

Wiemy już, jak oceniać czyn psychopaty; nie jest jednak łatwo znaleźć przekonujące podstawy do jego generalnego usprawiedliwienia. Pojawia się tu przede wszystkim kwestia wolności wyboru przez psychopatę alternatywnego zachowania zgodnego z prawem. Ludzi „moralnych” często coś powstrzymuje przed robieniem złych rzeczy, a jednak uważamy, że są oni wolni, gdy wybieraja „dobro”. Psychopatia to odwrotna strona tej samej monety. W świetle ocen społecznych swoista „inna moralność” z pewnościa nie jest okolicznościa usprawiedliwiająca: psychopata realizuje swoje cele, działając obok lub wbrew systemowi normatywnemu, a takie zachowania zasługują przecież na potępienie. Pozytywnym aspektem uznania psychopaty za przestępcę jest z pewnością potwierdzenie jego przyrodzonej godności, wyrażającej się w uczynieniu go w pełni odpowiedzialnym za popełniony czyn. W świetle ewolucyjnych koncepcji genezy psychopatii określenie „przyrodzona” nabiera tutaj jednak specyficznego smaku. Psychopata nie posiada zaplecza aksjologicznego, którym dla większości ludzi jest moralność. Czynnikiem skłaniającym psychopatę do zachowania zgodnego z normą może być niekiedy wyłącznie groźba kary, jest to jednak bardzo słaba determinanta nawet dla ludzi „moralnych”. Gdy człowiek nie miał możliwości poznania i zinternalizowania norm postępowania, postawienie mu zarzutu winy wydaje się wysoce dyskusyjne. Wskazane okoliczności należy brać pod uwagę, badając odpowiedzialność karną psychopaty za popełniony czyn zabroniony. Jeśli wina zostanie takiej osobie przypisana, osobowość sprawcy powinna zostać uwzględniona przy wymiarze kary, w ramach limitujaccej funkcji winy w rozumieniu art. $53 \S 1 \mathrm{k} . \mathrm{k}$. Na zmniejszenie stopnia winy psychopaty powinien rzutować przede wszystkim stopień internalizacji norm moralnych w kontekście warunków, w jakich sprawca się rozwijał, oraz indywidualny stosunek sprawcy do dóbr prawnych, zagrożonych lub naruszonych popełnionym czynem zabronionym.

Osadzenie w zakładzie karnym, jako reakcja na popełnione przestępstwo, wydaje się jedynym skutecznym sposobem ochrony społeczeństwa przed sprawcami najgroźniejszych zbrodni, którzy okazali się psychopatami. Ciśnie się na usta pytanie o sens oddziaływań resocjalizacyjnych wobec takich osób. Dostrzegana w praktyce nieskuteczność resocjalizacji psychopatów ${ }^{53}$ oznacza, że celem kary wymierzanej osobie z zaburzeniami psychopatycznymi jest wyłącznie jej izolacja od społeczeństwa.

${ }^{53}$ Zob. więcej: M. Ciosek, Psychologia..., op. cit., s. 206-208, wraz z przytaczaną tam literaturą. 
Jeszcze inną konsekwencją zaproponowanego rozumienia psychopatii jest niemożliwość stosowania wobec psychopatów środków zabezpieczających przewidzianych w Kodeksie karnym, z wyjątkiem stwierdzenia u sprawcy dodatkowych zaburzeń lub uzależnień, o których mowa w art. 93 k.k. (psychopata nie spełnia innych przesłanek opisanych w tym przepisie $\left.{ }^{54}\right)$. Inaczej należałoby natomiast zakwalifikować psychopatię na gruncie ustawy o postępowaniu wobec osób z zaburzeniami psychicznymi, stwarzających zagrożenie dla życia, zdrowia lub wolności seksualnej innych osób. Wydaje się, że psychopatię można podciagnąć pod „zaburzenie osobow ości”, stanowiące w myśl art. 1 pkt 2) tej ustawy jedna z przesłanek uznania sprawcy przestępstwa za osobę stwarzająca zagrożenie - nie jest to stan tożsamy z kodeksowo rozumianym zakłóceniem czynności psychicznych. Oznacza to, że w obecnym stanie prawnym istnieje możliwość zatrzymania psychopaty po odbyciu kary pozbawienia wolności (w razie spełnienia pozostałych warunków określonych w ustawie) w Krajowym Ośrodku Zapobiegania Zachowaniom Dyssocjalnym. Izolacja związana z umieszczeniem w ośrodku nie opiera się na przesłance winy i nie ma charakteru kary; nie jest reakcją na popełniony czyn zabroniony, lecz sposobem zabezpieczenia społeczeństwa przed niebezpiecznym człowiekiem $^{55}$.

\section{ZAKOŃCZENIE}

Zgodnie z badaniami prowadzonymi w naukach ewolucyjnych psychopatia może być rozumiana jako alternatywna strategia ewolucyjna. Na gruncie tej koncepcji sformułowaliśmy następujące hipotezy dotyczące kodeksowego rozumienia niepoczytalności oraz wartościowania czynu zabronionego popełnionego przez psychopatę w kategoriach winy:

1) Artykuł $31 \S 1$ k.k. nie jest adekwatnym wzorcem oceny zjawiska psychopatii. Prawidłowa prawnokarna kwalifikacja czynów psychopatów powinna się odbywać przez pryzmat art. 1 § 3 k.k. (ogólnej klauzuli zawinienia).

2) Gdy czyn psychopaty nie znajdzie usprawiedliwienia, kondycję jego osobowości należy każdorazowo uwzględniać przy wymiarze kary w ramach limitującej funkcji winy.

3) Osobowość psychopatyczna co do zasady nie podpada pod przesłanki stosowania środków zabezpieczających, określonych w k.k., kwalifikuje się za to jako zaburzenie osobowości, uzasadniajace stosowanie ustawy o postępowaniu wobec osób z zaburzeniami psychicznymi, stwarzających zagrożenie dla życia, zdrowia lub wolności seksualnej innych osób.

\footnotetext{
${ }^{54}$ Zob. A. Michalska-Warias, op. cit., s. 61-62.

55 Inna sprawa, czy stosowanie środków przewidzianych w omawianej ustawie jest zgodne z Konstytucja. Zob. A. Barczak-Oplustil, Środki reakcji prawnej wobec osób z zaburzeniami psychicznymi stwarzajacych zagrożenie życia, zdrowia lub wolności seksualnej innych osób w perspektywie zasad zawartych w Konstytucji, artykuł złożony do druku w „Czasopiśmie Prawa Karnego i Nauk Penalnych” 2014, nr 1.
} 
4) Nie budzi wątpliwości, że w toku postępowania karnego zdiagnozowanie psychopatii oraz określenie jej nasilenia wymaga zasięgnięcia opinii osoby posiadającej wiadomości specjalne (psychiatry). Ocena, czy popełnienie przez psychopatę czynu zabronionego było usprawiedliwione, wymyka się jednak spod kompetencji biegłego lekarza. Ostateczna ocena postępowania konkretnej osoby przez pryzmat przesłanek zawinienia należy do sędziego, powołanego do wymierzania sprawiedliwości.

\author{
dr Mikotaj Matecki \\ Uniwersytet Jagielloński \\ mikolaj.malecki@uj.edu.pl \\ dr Radostaw Zyzik \\ Akademia Ignatianum w Krakowie \\ radoslaw.zyzik@ignatianum.edu.pl
}

\title{
SANITY AND PSYCHOPATH'S GUILT IN LIGHT OF THE EVOLUTIONARY CONCEPTS OF THE ORIGIN OF PSYCHOPATHY
}

\section{Sum mary}

In the paper a thesis that psychopathy can be understood as a stable evolutionary strategy has been presented. We believe that this view may generate implications for criminal law, especially in the sphere of criminal responsibility. We propose a thesis that traditional understanding of legal insanity is not an adequate tool to assess the criminal actions of psychopaths. Moreover, the application of security measures may be de lege lata impossible. However, natural-born psychopaths can be isolated according to the provisions of the statue on proceedings against persons with mental disorders. 
Copyright of Journal of Law, Economics and Sociology is the property of Faculty of Law and Administration of Adam Mickiewicz University in Poznan and its content may not be copied or emailed to multiple sites or posted to a listserv without the copyright holder's express written permission. However, users may print, download, or email articles for individual use.

Właścicielem praw autorskich do „Ruchu Prawniczego, Ekonomicznego i Socjologicznego” jest Wydział Prawa i Administracji Uniwersytetu im. Adama Mickiewicza w Poznaniu. Zawartość czasopisma nie może być kopiowana, przesyłana do innych stron internetowych bądź zamieszczana na blogach bez pisemnej zgody wydawcy. Niemniej artykuły można drukować, kopiować lub przesyłać w formie elektronicznej na własny użytek. 